\title{
Urban drainage control applying rational method and geographic information technologies
}

Research Article

\author{
Beatriz Aldalur $^{1 *}$, Alicia Campo², Sandra Fernández ${ }^{1}$ \\ 1 Departamento de Ingeniería, Universidad Nacional del Sur (UNS) Av. Alem 1253, (8000) Bahía Blanca, Argentina \\ 2 Departamento de Geografía y Turismo, Universidad Nacional del Sur (UNS) Consejo Nacional de Investigaciones Científicas y \\ Técnicas (CONICET) $4^{\circ}$ piso, 12 de Octubre y San Juan, (8000) Bahía Blanca, Argentina
}

Received 14 June 2012; accepted 21 June 2013

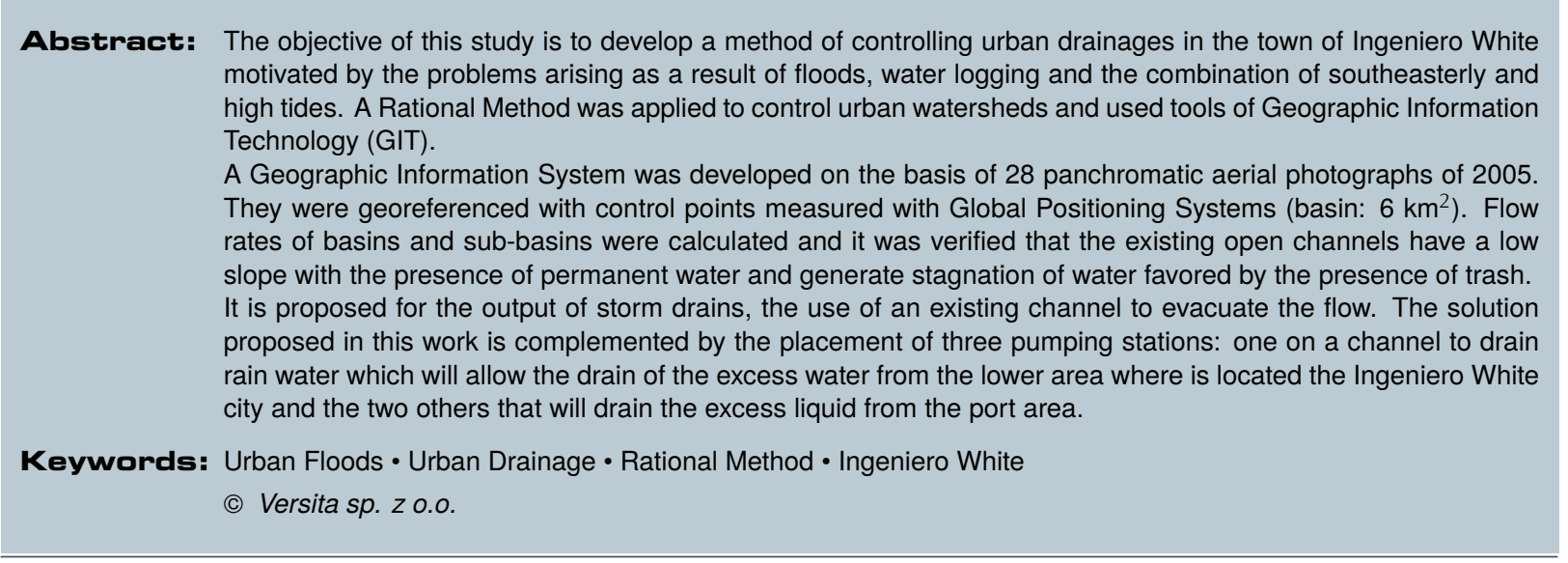

This presentation corresponds to the Project The Physical Geography of the South of Buenos Aires province. Relationship between man and the natural environment. It has the support of the SGCyT of the Universidad Nacional del Sur. Projet Director: Dr. Alicia M. Campo, amcampo@uns.edu.ar.

*E-mail: baldalur@hotmail.com

\section{Introduction}

This work was developed in an area of about 600 hectares that make up the basin where is situated the town of Ingeniero White. Located at $38^{\circ} 44^{\prime} 06^{\prime \prime}$ South latitude and $62^{\circ} 14^{\prime} 02^{\prime \prime}$ West longitude, about $7 \mathrm{~km}$ from the city of Bahía Blanca, República Argentina, this town gives name to an important grain export harbor and general charges. When it combines strong winds from the South and Southeast, known locally as "Sudestada", intense rainfall and high tides over the maximum mean values, flooding of streets and avenues of access to the town of Ingeniero White, as well as water intrusion located in houses below 
the level of roadside cord, happen in the studied area. These events of waterlogging and flooding were witnessed by the local press since the beginning of the twentieth century and are conflicts that were originated by the advance of man on the natural environment and the lack of regulation of land use.

The "Sudestada": It is a meteorological phenomenon common to a large region of the South and Southeast of Buenos Aires province. It is characterized by cold or cool and intense winds from the Southeast quadrant with speeds above $35 \mathrm{~km} / \mathrm{h}$, rainfall of different intensity, low temperature and moisture in successive days from the ocean $[1,2]$.

The development was increased in the studied area without the appropriate adaptation to the growth of the infrastructure of the city. When the areas are urbanized upstream from the sectors which already have a drainage system, they will become obsolete or are unable to evacuate the greatest streams that are generated by having waterproofed these areas. The studied area is emplaced at an altitude between 3 to 10 meters above the sea level with origin at the adopted level by the National Geographic Institute (NGI), taking as the southern limit of Bahia Blanca estuary.

The whole area forms a lower zone, surrounded by nonpermanent water channels which pass through passable land with sparse and little vegetation. Benedetti [3] describes it as a coastal area covered with halophytic vegetation, with large flat land, with the presence of plants and shrubs, interspersed with bare and whitish spaces. It is a coastal area that highlights the clay and brackish soils and salty grass. The coast of the estuary, to the height of $10 \mathrm{~m}$, is occupied by halophytic steppe composed of shrubs, subshrubs and herbs halophytes, which become confused with species of the pampean steppe and dry forest [4]. The main problem that arises in the studied area is to drain and evacuate the any excess of water that occurs when heavy rains happen in conjunction with the increase in tidal heights. It should lead the excess water through networks of collectors into the nearest natural channel that is the Bahia Blanca estuary. Figure 1 shows the location of the studied area.

The problems of flooding and waterlogging in combination with high tides from the Southeast led to the goal of this work is to develop a method of control of urban drainage in Ingeniero White town. To satisfy with the proposed objective it was used the Rational Method for the control of basins and it was used tools of Geographic Information Technology (TIG).

The Geotechnologies or TIG are a set of tools that facilitate the collection, management and analysis of different data [5-7]. TIG support new forms of research in various disciplines especially those associated with the Earth Sciences [8]. These digital technologies offer many applications being the GIS the tool that includes them and through which socio-spatial analyzes are performed in order to provide solutions to the problems of management and territorial planning [9]. The Geographic Information Systems currently make up an indispensable tool for technical analysis involving territorial spaces, particularly the various political managers and in the decision making of a territory [10]. An essential requirement for these analyzes and consistent evaluations were correct is to count with reliable information [11]. The georeferentiation (latitude, longitude, height) is the common element between the various databases that can link them together.

\section{Materials and methods}

It was developed a Geographic Information System (GIS) assembled on the basis of 28 panchromatic rectified aerial photographs of 2005, they were georeferenced with ground points surveyed in the field using Global Positioning Systems (GPS). The GIS chosen was ArcView 3.1 with the extensions Image Analysis and 3D Analyst. The GIS ArcView 9.1 was used for the output map.

Aerial photographs from 2005 and the existing databases in the Dirección de Vialidad Municipal were taken as basis. They include the urban area of Ingeniero White town. The photographs used were scanned at a resolution of $500 \mathrm{dpi}$, allowing to work with a pixel size of $0.051 \mathrm{~mm}$ in the photo whose correspondence is of $0.254 \mathrm{~m}$ on the ground.

For the georeferencing of aerial photography, GPS geodesic equipments of dual-frequency Trimble 4800 were used and control points through determinations relating were surveyed. The method used, the static differential positioning, is the most suitable method for measuring long bases since long observation sessions allow a careful treatment of systematic errors [12]. This means that it's worked with two machines simultaneously positioned over two points that observed the same satellites synchronously. One of the points, called the base point, was the Bahía Blanca Permanent Station (EPBB) and is located in the Universidad Nacional del Sur on a trigonometric point called VBCA (Vínculo Bahía Blanca). Its coordinates are known accurately and is linked to the Red POSGAR (Posiciones Geodésicas Argentinas). This point is part of the Permanent Stations, incorporated into the project RAMSAC (Red Argentina de Monitoreo Satelital Continuo) that IGN counts in Argentina. It was corrected differentially each point doing this processing with the program Trimble Geomatic Office. 


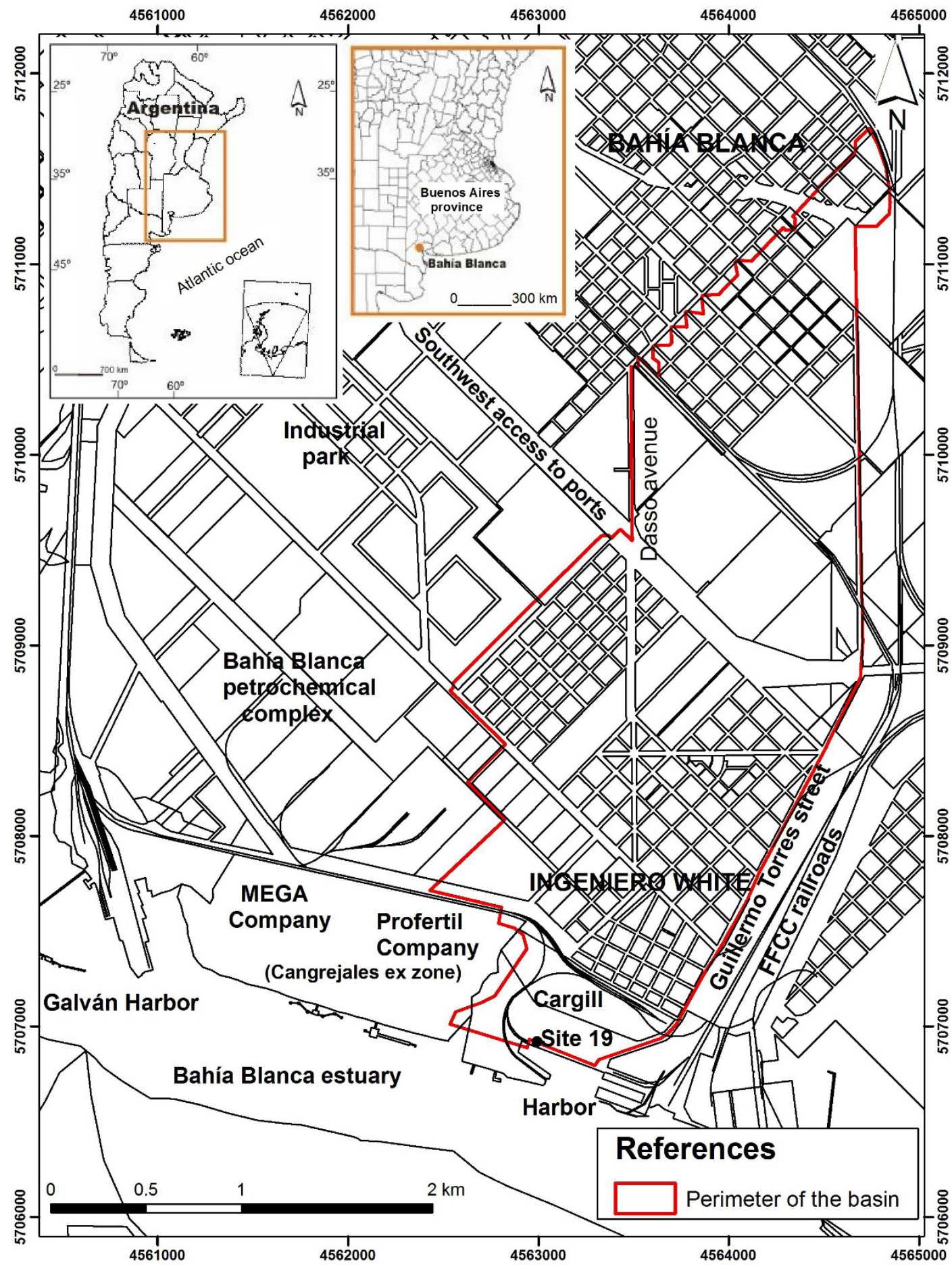

Source: Own elaboration (Dra. Agrim. Beatriz Aldalur) based on the vectorial file of the Bahía Blana Municipality, georeferenced with ground control points.

Figure 1. Location of the studied area. 
Aerial photographs were the basis on which the different layers were subsequently digitized. The photographs did not have any kind of correction, the flight was not rectified or restituied, therefore they had the errors produced by the airplane: relief effect error, inclination error of the aerial camera and scale error. These last two errors were corrected by performing the correction of each photograph. Since the studied area constitutes a nearly flat topography it was not necessary to perform orthophotos.

The information about levels of natural ground height was digitized and loaded into the GIS. These data were extracted from the paving project plans and geometric planes levelings made by private professionals.

An analysis of the status and location of the various works that form the current network of storm drains and sewers was performed. The entire area drained has actually 3 outlets of storm drains to the estuary, which modified the original situation of the basin. Two of them made up by tubes that dump their waters into the Ingeniero White port and a third through an open channel located in the eastern sector of the Profertil company, actually called "Profertil channel". The construction of the first storm drains in Ingeniero White dating from before 1963, filing date of the first plans detailing the location of two of the three current outputs to the estuary. The sewage ends up in a single collector that enters in the treatment plant liquid sewage located just meters from the estuary at the entrance to the Polo Petroquímico on the path that leads to Puerto Galván (Figure 1). The fluid is sent to the estuary after being treated by drain pumps or drive pumps. The sewer pipe is attached to carrying rainwater to the sea, leaving all the fluid in the Site 19 (Figure 1).

The Ingeniero White town sent at the beginning, its stormwater to the sea through a channel with gate located at a place called Cangrejales. This place is now occupied by the company Profertil and the channel was moved a few meters to the port area in the years 2001 to 2002.

In 2002, drains were improved and works were performed by adding channels to conduct open water more quickly into the estuary. The cleaning of these channels is not performed continuously by the municipality, so that they are invaded by existing waste material on the sidewalks and sediments carried by water. The same effect occurs on sinks, where trash does not allow the total income of meteoric waters. The maintenance of the artificial channels that lead the rainwater is a major problem in the studied basin, some of them suffer from erosion and the vast majority of sedimentation. Sinks or storm drains and open channels should be cleaned continuously so that the trash that goes into them does not slow the normal drainage of rainwater.
The existing open channels in the studied area have permanent water due to the low slope that they have. The low slope leads to reduced flow rates that promote water stagnation. There is much material transported by water sedimentation and change the depth and slope to the different channels. Litter is a recurring parameter in all cases. Many open channels end connected to pipes. On the basis of the contour lines and ducts and open channels located on the studied area, 3 basins were delineated. One was at the same time divided into 26 sub-basins as shown in Figure 2.

Figure 3 shows the location of the various sinks, pipes and open channels of the studied area. The information of each pipe and channel was loaded into the GIS attribute table. The figure also shows the names and the details of the channels (Ca) and ducts (Co) whose capacity was controlled. The detail shown in Figure 4 shows the sector of the old town of Ingeniero White. This detail is presented because the vast majority of sinks and pipes are placed in this specific area.

Information incorporated in GIS allowed working in the computation of the flow of each basin and sub-basin. The most used method for the study of urban watersheds is Rational Method [13] as it enables the estimation of the flood flow and achieves a better fit to small basins [14] besides being the standard calculation method required for the submission of drainage projects in Buenos Aires province [15]. Experience has shown that Rational Method should only be applied to catchments under $13 \mathrm{~km}^{2}$ as there is a small lag between rainfall and peak flow. Even though it has applicability to watersheds of $100 \mathrm{~km}^{2}$, its use is recommended in basins under $15 \mathrm{~km}^{2}$ [16].

According to Castillo Sánchez [17] this method is valid for small basins, setting the limit at $25 \mathrm{~km}^{2}$, although the results are acceptable up to $50 \mathrm{~km}^{2}$. In the studied basin case, the total area is approximately $6 \mathrm{~km}^{2}$, which is within the limits recommended by different authors.

Senciales González [14] states that the forecasts can exceed reality in the most time intensity rainstorms, but the Rational Method shows a good fit in most common rainstorms and especially as already mentioned, on smaller scale basins. Rational Method is widely used for sewer design due to its simplicity, relates surface of the basin with the average intensity of rainfall and runoff coefficient resulting.

The ductwork that will carry stormwater and the sewer's design of a given basin [18] is calculated using the formula of discharge:

$$
Q=0.278 \cdot C . I . A
$$

where $Q$ : discharge $\left(\mathrm{m}^{3} / \mathrm{s}\right)$ is the flow rate at the outlet of the watershed when it reaches equilibrium, the maximum or peak discharge [16]; $C$ : runoff coefficient, a constant 


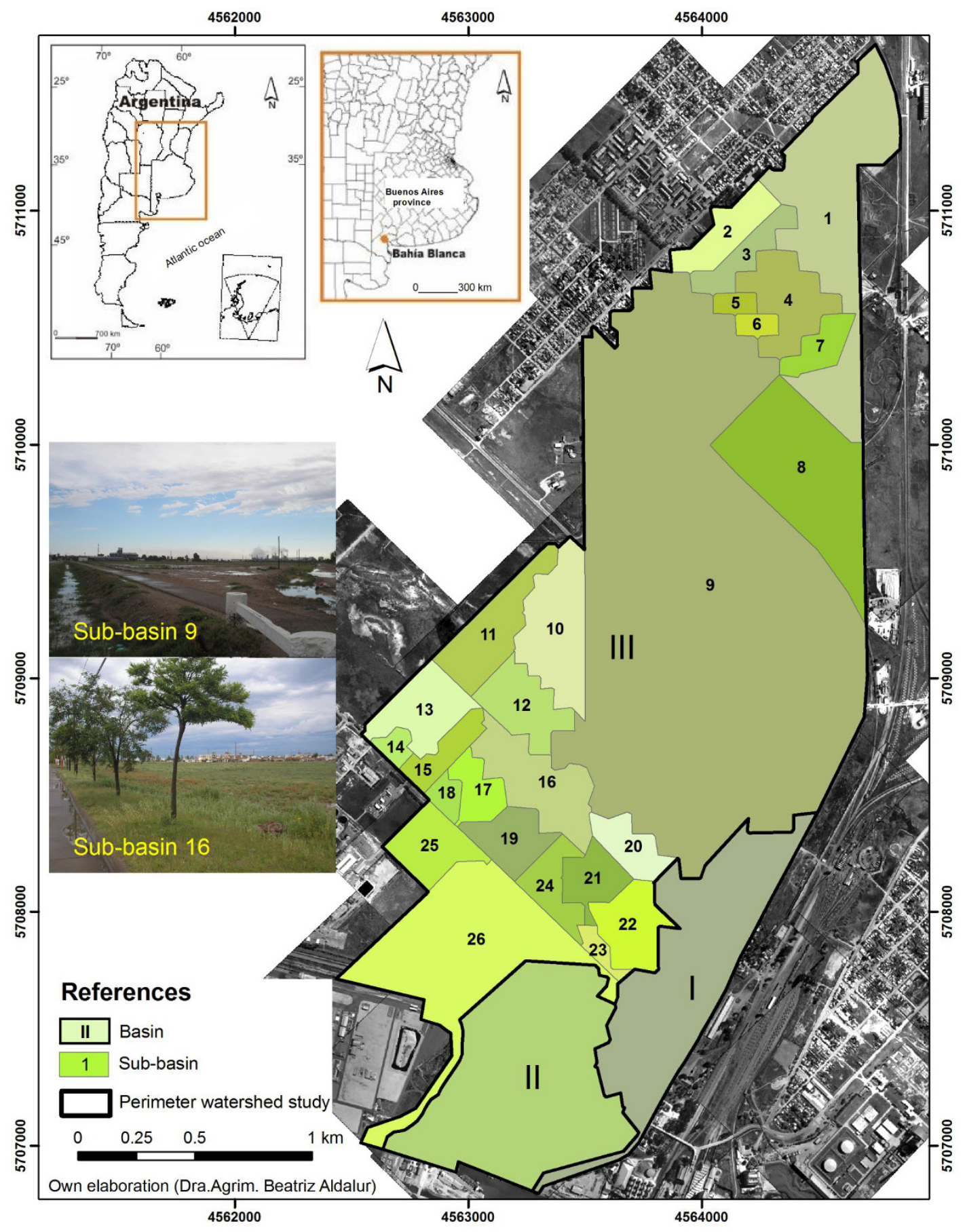

Figure 2. Cartographic representation of the different basins and sub-basins. 


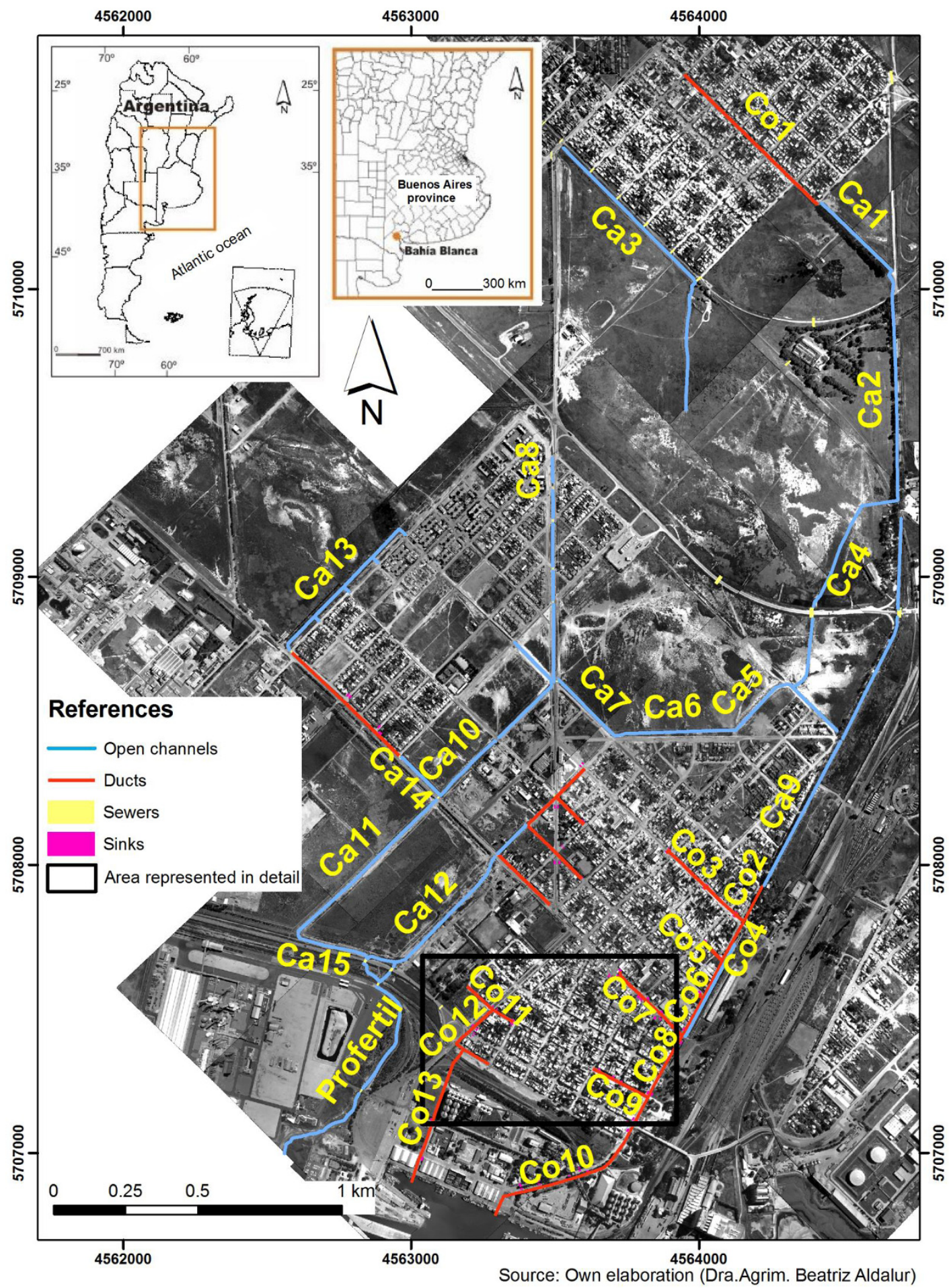

Figure 3. Location of storm water pipes, open channels, sinks and sewers. 

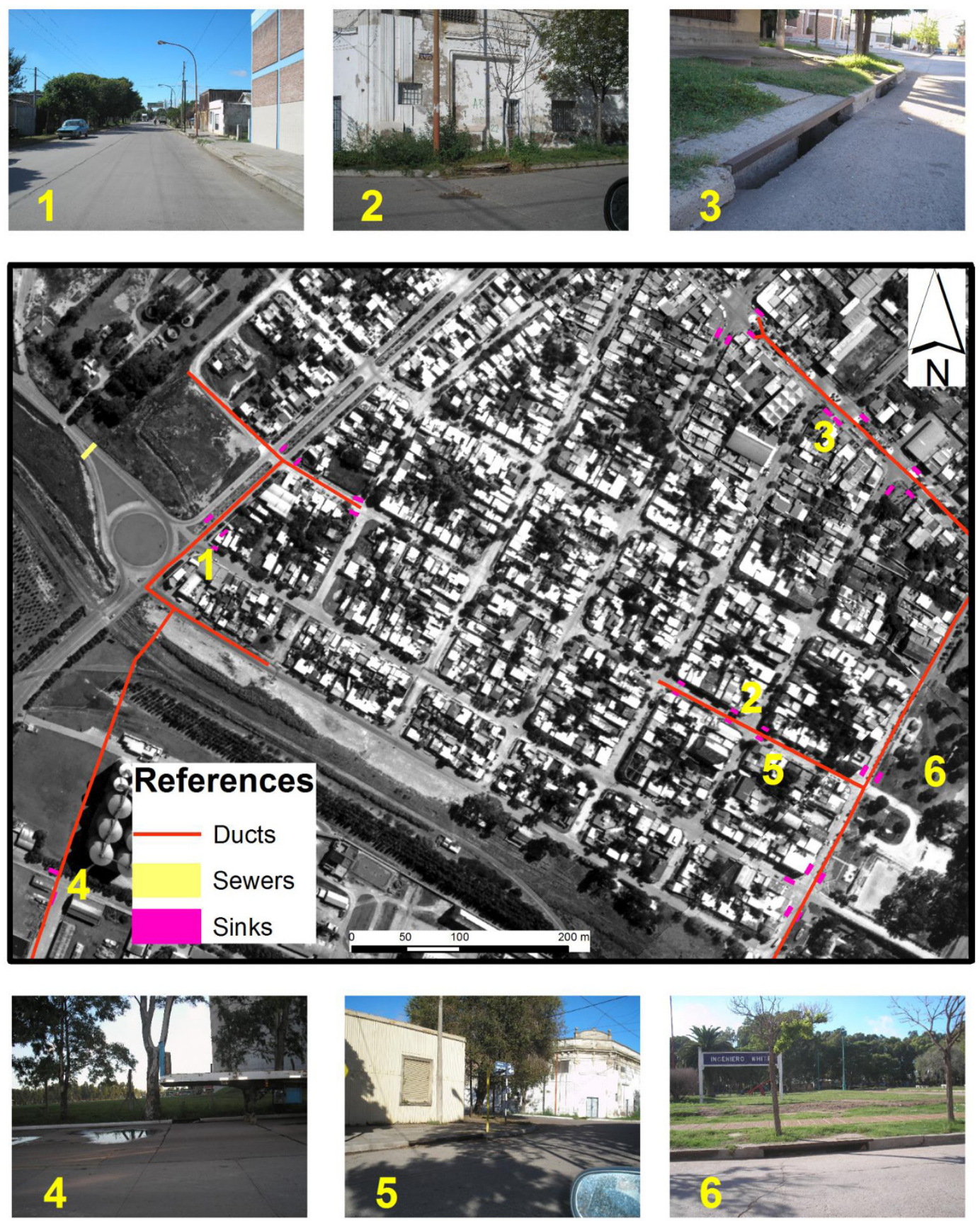

Source: Own elaboration (Dra.Agrim. Beatriz Aldalur)

Figure 4. Detail of the enlargement area included in Figure 3. 
that is obtained by using tables dependent on the nature of the surface within the drainage area and takes values between zero and one $(0 \leq C \leq 1)$; $l$ : rainfall intensity that begins instantaneously and continues indefinitely until all the watershed is contributing to flow at the outlet $(\mathrm{mm} / \mathrm{h})$ and $A$ : drainage area $\left(\mathrm{km}^{2}\right)$. Rational Method main idea is that if a rain with intensity I instantly begins and continues indefinitely, runoff rate will continue to the time of concentration $\left(t_{c}\right)$, time in which the entire basin contributes in the flow of output. According to Chow et al. [18] the product of rainfall intensity $(I)$ and basin area $(A)$ is flow rate input into the system $(I \cdot A)$. The relationship between flow rate and peak flow $(Q)$ is known as runoff rate $(C)$ [18].

The calculation of the maximum flow rate was then used to control the design of the different channels, ducts and sewers. In this method it is assumed that rainwater is constant throughout the storm and falls the same way throughout the basin. The maximum discharge for each basin and sub-basin of the studied area was calculated with the program HidroEsta [19] which provides the results through the use of Rational Method.

To calculate the flow rates of each basin and sub-basin, it must have information about the area, rainfall intensity and runoff coefficient. These variables are discussed in the following sections.

Runoff Coefficient: is a coefficient that depends on the percent imperviousness, slope and ponding character of the surface. It is defined as the ratio of the flow rate runs off the surface to the total flow. For example, asphalt surfaces will produce nearly 100 percent runoff. This ratio also depends on soil conditions, rainfall intensity, proximity of the water table, soil type (porosity and compaction) and vegetation [18]. There are tables that allow its calculation.

Provincial Department of Sanitation and Water Works MOSP [15] for Buenos Aires province, recommends the use of runoff coefficients consistent with urban development of the area. Not advisable to use lower ratios of $C=0.40$ for unpaved areas and $C=0.60$ in paved areas. Field inspection and aerial photographs were very useful in estimating nature of surface within the drainage area. Information on the status of streets and land use was extracted from GIS, which was previously digitized. Figure 5 shows the cartography for streets which are paved, cobbled and ground which is one of the data used to calculate this coefficient.

Various surfaces were calculated to cover different land uses in each basin and sub-basin. This task was carried out with information that was incorporated into the GIS through photo interpretation and field work. Figure 6 shows the current land use for the studied area.
Table 1 shows, as an example, the calculation of coefficients by the HidroEsta [19] software for the basin II. The column destined to area is in hectares and was calculated by the GIS. The ratio calculated is the weighted (the sum of the coefficients which arise from multiplying the percentage of space allocated to each land use by the coefficient for that use). For each of the different basins and sub-basins was generated a similar table.

The different coefficients obtained using the software HidroEsta [19] showed similar results to those coefficients which are tabulated in Chow et al. [18] which validates the use of the program.

\section{Area of each basin and sub-basin}

The area of each basin and sub-basin was calculated in the GIS through query mode tools. Different drainage divisions were defined considering the slopes of the pavements and the contour curves of the studied area. The drainage area that contributes to the whole system and the area of the different basins and sub-basins that contribute to each of the entry points are shown in Figure 2.

\section{Rate rain}

The rainfall intensity $(I)$ is the average rainfall rate in inches per hour or millimeters per hour, for a drainage basin or sub-basin. The value of $I$ is chosen on the basis of the duration of design rainfall and return period. The design duration is equal to the time of concentration for the drainage area considered and the return period is set according to design standards. Runoff reaches its peak at the concentration time when the entire basin is contributing to flow at its outlet [18].

The time of concentration proposed by Kirpich [20] and recommended by Pérez Morales and Rodríguez Castro [16] and Senciales González [14] is:

$$
t_{c}=\left[\frac{0.87 \cdot L^{3}}{H}\right]^{0.385} \quad \text { for watershed area }<50 \mathrm{~km}^{2}
$$

where $t_{c}$ is the time of concentration (h); $L$ : length of longest watercourse to outlet $(\mathrm{km}) ; \mathrm{H}$ : elevation difference between headwater to outlet $(\mathrm{m})$.

Time of concentration values determined by the software HidroEsta [19] for each of the basins and sub-basins were checked through the application of the formula proposed by Kirpich [20], giving the same results. Therefore the methodology applied by the program for the calculation of 


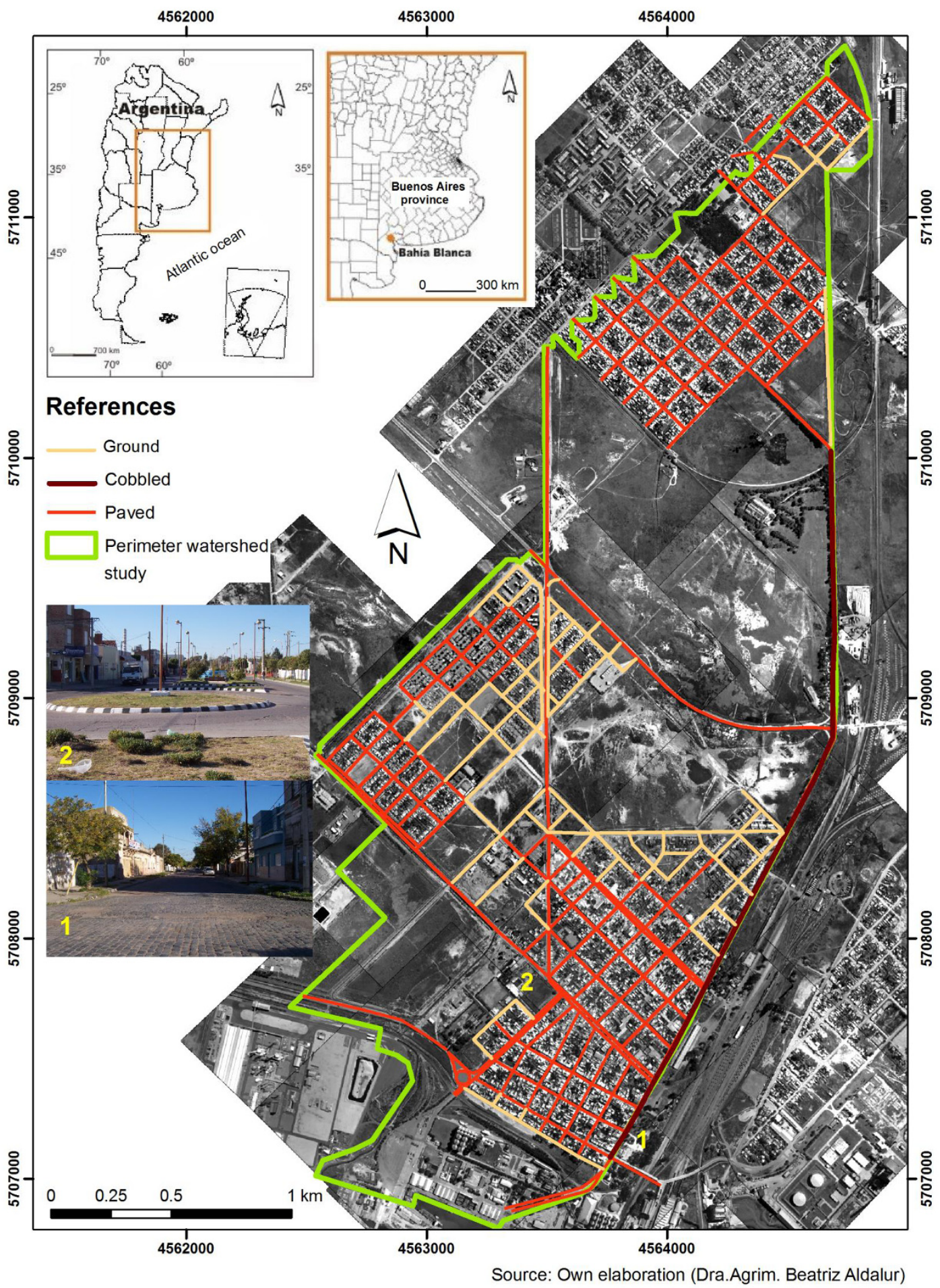

Figure 5. Mapping of paved, ground and cobbled streets. 


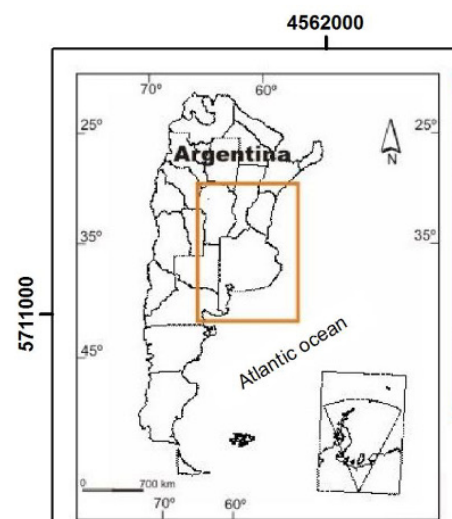

\section{References}

은

$\square$ Urbanized unbuild
$\square$ Residential

(6)

:

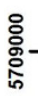

Commercia

Parking

Not urbanized

Residential housing district

Health

Education

$-2$

Offices, entities, societies, guilds

Recreation (clubs, squares)

Security (police, firemen)

Religious

Perimeter of the basin
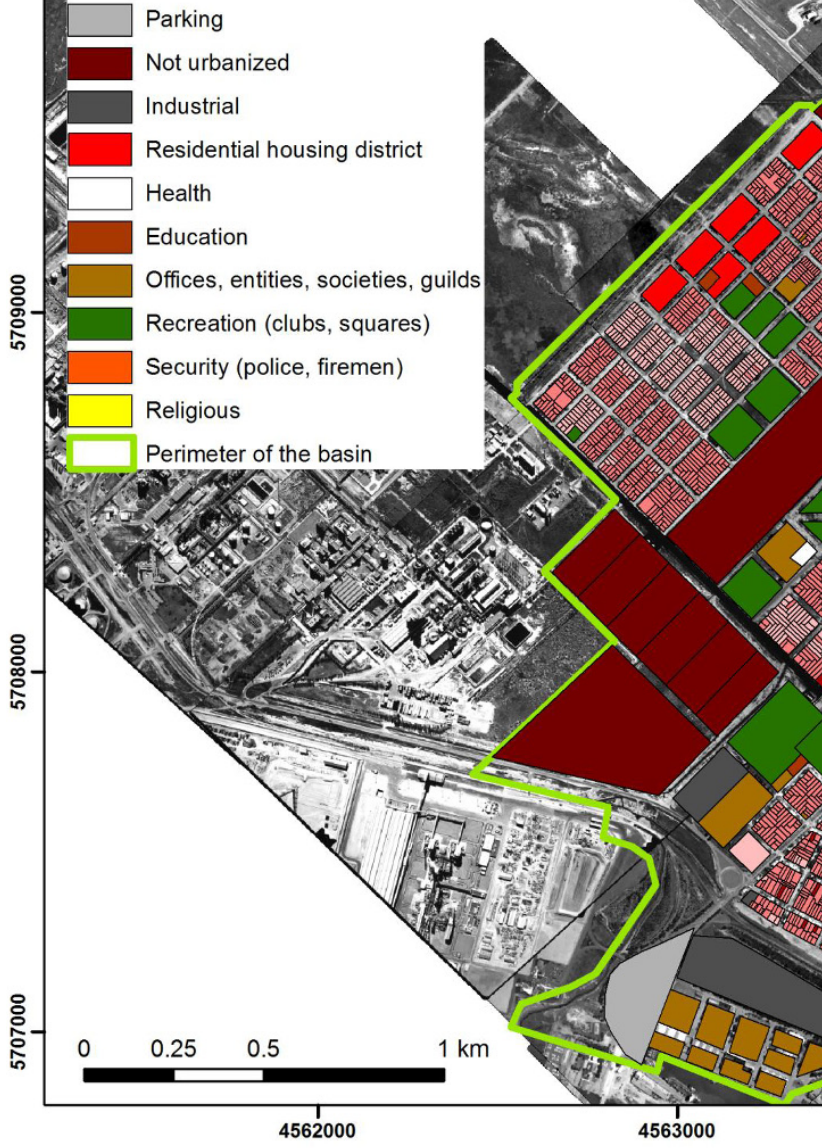

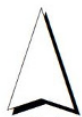

4564000

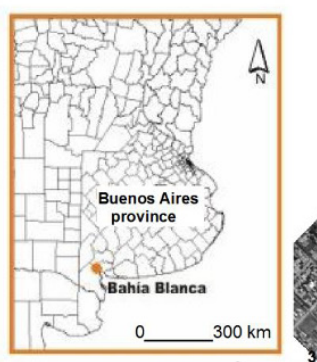

ans

- 울

ㅇํํ

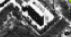

Figure 6. Land use of 2010 
Table 1. Runoff coefficient and area of the diferent uses for the sub-basin II.

\begin{tabular}{llll}
\hline & Area (ha) & Land use & Coefficient \\
\hline 1 & 7.7185 & central comercial areas & 0.95 \\
2 & 0.5000 & neighborhood comercial areas & 0.70 \\
3 & 11.3100 & single families residential & 0.50 \\
4 & 0.1714 & separate multifamily & 0.60 \\
5 & 0.5871 & industrial areas spaced & 0.80 \\
6 & 1.9710 & game fields & 0.35 \\
7 & 21.9980 & yards of railroad & 0.40 \\
8 & 12.0750 & paved streets & 0.95 \\
9 & 4.6310 & parkings & 0.85 \\
10 & 0.6862 & wasteland & 0.35 \\
Total & 61.6482 & C weighted & 0.63 \\
\hline
\end{tabular}

maximum precipitation intensity and concentration time is evaluated.

To calculate the value of the intensity of rainfall, the curves named Intensity-Duration-Frequency (IDF) were used. Sequeira [21] mapped out the curves for the city of Bahia Blanca from 248 rains of high intensity and short duration, moderate intensity and long duration with data from the Meteorological Station Bahia Blanca under the National Weather Service recorded since the 04/05/51 to $12 / 03 / 88$. As for the return period, the Provincial Department of Sanitation and Water Works - MOSP [15] in the Buenos Aires's province requires 5 years minimum value for the case of verification of channels.

Table 2 presents the different values of rainfall intensity extracted from the IDF curves for Bahia Blanca by Sequeira [21]. The maximum rainfall intensity for each basin and sub-basin it must be calculated. This value allows the calculation of the discharge that contributes to the flow throughout the basin.

\section{Results and discussion}

Based on the results obtained using the above information incorporated to the HidroEsta program and using the information to sub-basin level, the discharge for a return period of 5 years was obtained. Table 3 presents the results of $C, I$ and $Q$ for each of the 28 basins and subbasins of Ingeniero White. The discharge for the total area or the entire basin is $22.41 \mathrm{~m}^{3} / \mathrm{s}$.

The information from the slopes of open channels and conducts (extracted from the paving project plans and incorporated into the GIS) and discharge information calculated, allowed to verify the sections that the storm sewer pipes of each basin and sub-basin must have to
Table 2. Return period, duration and intensity of rain. Source: Sequeira, 2006.

\begin{tabular}{llll}
\hline & T (years) & $\begin{array}{l}\text { Duration } \\
(\mathbf{m i n})\end{array}$ & $\mathrm{I} \max (\mathrm{mm} / \mathrm{h})$ \\
\hline 1 & 5 & 5 & 90 \\
2 & 5 & 10 & 72 \\
3 & 5 & 15 & 60 \\
4 & 5 & 20 & 52 \\
5 & 5 & 25 & 46 \\
6 & 5 & 30 & 41 \\
7 & 5 & 35 & 37 \\
8 & 5 & 40 & 34 \\
9 & 5 & 45 & 32 \\
10 & 5 & 50 & 29 \\
11 & 5 & 55 & 28 \\
12 & 5 & 60 & 26 \\
13 & 5 & 80 & 21 \\
14 & 5 & 100 & 18 \\
15 & 5 & 120 & 16 \\
\hline
\end{tabular}

transport by gravity the water forward the estuary. It was used a 5 years return period as stated in the existing regulation, because there was no information about the return period for which these pipes were calculated.

For the mentioned testing it was used the program HCanales [22]. This program is used for the design of channels and hydraulic structures. It works with the above data and uses the Manning equation [18] transcribed below. The formula (3) calculates the values of width and height of a channel and (5) the diameter of the ducts:

$$
Q=\frac{1}{n} \cdot \sqrt{S} \cdot A \cdot R^{\frac{2}{3}}
$$


Table 3. Flow calculation for a return period of 5 years.

\begin{tabular}{|c|c|c|c|c|}
\hline Basin & $\begin{array}{l}\text { Sub- } \\
\text { basin }\end{array}$ & $\mathrm{C}$ & I max.(mm/h) & $Q \max .\left(m^{3} / s\right)$ \\
\hline I & - & 0.63 & 19.36 & 1.66 \\
\hline II & - & 0.63 & 35.40 & 3.78 \\
\hline III & 1 & 0.48 & 28.31 & 1.51 \\
\hline III & 2 & 0.49 & 37.31 & 0.35 \\
\hline III & 3 & 0.68 & 40.07 & 0.38 \\
\hline III & 4 & 0.59 & 45.84 & 0.81 \\
\hline III & 5 & 0.63 & 79.07 & 0.14 \\
\hline III & 6 & 0.62 & 80.16 & 0.14 \\
\hline III & 7 & 0.53 & 46.97 & 0.27 \\
\hline III & 8 & 0.33 & 33.44 & 0.94 \\
\hline III & 9 & 0.35 & 22.70 & 4.64 \\
\hline III & 10 & 0.57 & 34.91 & 0.81 \\
\hline III & 11 & 0.64 & 34.37 & 0.67 \\
\hline III & 12 & 0.33 & 73.12 & 0.60 \\
\hline III & 13 & 0.52 & 31.06 & 0.45 \\
\hline III & 14 & 0.64 & 75.51 & 0.13 \\
\hline III & 15 & 0.59 & 39.04 & 0.26 \\
\hline III & 16 & 0.43 & 39.55 & 0.65 \\
\hline III & 17 & 0.53 & 42.78 & 0.25 \\
\hline III & 18 & 0.68 & 79.56 & 0.30 \\
\hline III & 19 & 0.42 & 64.04 & 0.52 \\
\hline III & 20 & 0.63 & 41.54 & 0.36 \\
\hline III & 21 & 0.61 & 46.31 & 0.39 \\
\hline III & 22 & 0.62 & 30.30 & 0.41 \\
\hline III & 23 & 0.68 & 57.70 & 0.11 \\
\hline III & 24 & 0.47 & 41.73 & 0.27 \\
\hline III & 25 & 0.35 & 57.35 & 0.44 \\
\hline III & 26 & 0.37 & 28.57 & 1.18 \\
\hline Total & & & & 22.41 \\
\hline
\end{tabular}

$$
R=\frac{A}{P}=\frac{\pi \cdot D^{2}}{4 \pi \cdot D}=\frac{D}{4}
$$

$R$ is replaced in (3) and is obtained:

$$
D=\left(\frac{3.21 \cdot n \cdot Q}{\sqrt{S}}\right)^{\frac{3}{8}}
$$

where $Q$ : discharge $\left(\mathrm{m}^{3} / \mathrm{s}\right) ; D$ : pipe diameter $(\mathrm{m}) ; S$ : slope; $n$ : Manning's roughness coefficient (in the technical system, the unit is $\left.\mathrm{s} / \mathrm{m}^{\frac{1}{3}}\right)$; A: area of the section of duct $\left(\mathrm{m}^{2}\right) ; R$ : hydraulic ratio $(\mathrm{m})$ and $P$ : perimeter of duct $(\mathrm{m})$. The Manning roughness coefficient was extracted from the table prepared for channels of different classes. It is a table showing minimum, normal and maximum of $n$. Normal values for artificial channels are recommended only for well-maintained channels [23].
The result of $\mathrm{n}$ extracted from the table Manning is 0.013 for concrete and 0.025 for earth channel. Table 4 presents the results of verification and the diameters of the tubes and the height and width of the channels. The location of each channel and conduit was detailed in Figure 3.

The verification showed that the diameters or sections of some installed ducts are lower and others are larger, according to the calculated discharge. The conducts 1,6 , 8,10 and 11 have a smaller diameter than the calculated. Conducts 3, 5, 7, 9 and 13 are correctly dimensioned. No information was available on the true diameter of the rest of the ducts.

All channels have the width and height calculated. From field inspection can be notice that existing open channels in the studied area have permanent water due to the low slope. The low slope leads to reduce flow velocities 
Table 4. Results obtained of calculation of ducts and channels.

\begin{tabular}{|c|c|c|c|c|c|c|c|}
\hline $\begin{array}{l}\text { Duct (Co) } \\
\text { or channel (Ca) }\end{array}$ & $\begin{array}{l}Q \\
\left(\mathrm{~m}^{3} / \mathrm{s}\right)\end{array}$ & Slope & $\begin{array}{l}\text { Coefficient } \\
\text { of Manning }\end{array}$ & $\begin{array}{l}\text { Diameter } \\
\Phi(\mathrm{m})\end{array}$ & $\begin{array}{l}\text { Width } \\
\text { b (m) }\end{array}$ & $\begin{array}{l}\text { High } \\
\text { h (m) }\end{array}$ & $\begin{array}{l}\text { Information: } \\
\text { diameter buildt }\end{array}$ \\
\hline Co1 & 3.328 & 0.001300 & 0.013 & 1.65 & & & 1.40 \\
\hline Ca1 & 3.600 & 0.003600 & 0.025 & - & 1.20 & 0.910 & - \\
\hline $\mathrm{Ca} 2$ & 4.070 & 0.004400 & 0.025 & - & 1.30 & 0.900 & - \\
\hline $\mathrm{Ca} 3$ & 0.469 & 0.002600 & 0.025 & - & 1.20 & 0.340 & - \\
\hline Ca8 & 2.800 & 0.003700 & 0.025 & - & 1.80 & 0.687 & - \\
\hline $\mathrm{Ca} 4$ & 5.280 & 0.002400 & 0.025 & - & 2.80 & 0.900 & - \\
\hline Ca5 & 3.240 & 0.001200 & 0.025 & - & 2.80 & 0.830 & - \\
\hline Ca10 & 7.210 & 0.001300 & 0.025 & - & 3.50 & 1.135 & - \\
\hline Ca11 & 7.210 & 0.000260 & 0.025 & - & 5.00 & 1.500 & - \\
\hline Ca11 & 7.820 & 0.001200 & 0.025 & - & 4.00 & 1.140 & - \\
\hline Ca12 & 1.790 & 0.000700 & 0.025 & - & 2.00 & 0.870 & - \\
\hline Ca9 & 2.800 & 0.000840 & 0.025 & - & 2.45 & 0.900 & - \\
\hline Co2 & 2.800 & 0.000840 & 0.013 & 1.70 & - & 1.360 & - \\
\hline Co3 & 0.170 & 0.001000 & 0.013 & 0.60 & - & 0.440 & 0.6 \\
\hline Co 4 & 2.970 & 0.000920 & 0.013 & 1.70 & - & 1.380 & - \\
\hline Co5 & 0.137 & 0.002400 & 0.013 & 0.60 & - & 0.284 & 0.6 \\
\hline Co6 & 3.400 & 0.000990 & 0.013 & 1.80 & - & 1.380 & 1.2 \\
\hline Co7 & 0.294 & 0.002200 & 0.013 & 0.60 & - & 0.480 & 0.8 \\
\hline Co8 & 3.690 & 0.001000 & 0.013 & 1.80 & - & 1.500 & 1.2 \\
\hline Co9 & 0.182 & 0.001600 & 0.013 & 0.60 & - & 0.380 & 0.6 \\
\hline Co10 & 3.870 & 0.001000 & 0.013 & 1.80 & - & 1.620 & 1.2 \\
\hline Co11 & 0.388 & 0.000800 & 0.013 & 0.80 & - & 0.690 & 0.6 \\
\hline Co12 & 0.388 & 0.001100 & 0.013 & 0.75 & - & 0.660 & - \\
\hline Co13 & 1.150 & 0.001100 & 0.013 & 1.20 & - & 0.880 & 1.6 \\
\hline Ca13 & 1.120 & 0.000400 & 0.025 & - & - & 0.820 & - \\
\hline Ca14 & 0.652 & 0.003800 & 0.025 & - & 1.50 & 0.400 & - \\
\hline Ca15 & 1.380 & 0.001170 & 0.025 & - & 1.00 & 0.700 & - \\
\hline Projected & 3.860 & 0.000296 & 0.013 & 1.75 & 1.50 & 1.530 & Projected \\
\hline
\end{tabular}

that promote water stagnation. Sedimentation of much material transported by water, change the depth and slope of various channels. Litter is a recurring parameter in all of them. Is necessary a permanent maintenance so they can maintain the depth and width required for flow transportation. Many open channels have their outlet connected to pipes.

\section{Conclusions}

To resolve the explained problems it is necessary to make a duct with the characteristics detailed in Table 4 where it is described as a projected duct. This line should connect the two existing storm drains at present and should drain into the Profertil channel. The two water outputs must be closed. Its location can be seen in Figure 7 and an enlargement detail in Figure 8.

The output of the Ingeniero White storm drains to the estuary, would be done through an existing channel, that must be deepened so it can evacuate the largest flow. The solution proposed in this work is complemented with the placement of three pumping stations: one on the Profertil channel and the two others in the current output of both stormwater pipes. The pump to be placed on the Profertil channel meets the objective of draining the excess water from the entire lower area where is located the city of Ingeniero White. The other two pumps will drain the fluid that may remain in the port area when the two exits to the estuary were closed.

The drainage network of the studied area was diagrammed at different times and stages. Urban growth led to exceeding flows for which the network was calculated. While in some sections it has been improved, as in the case 


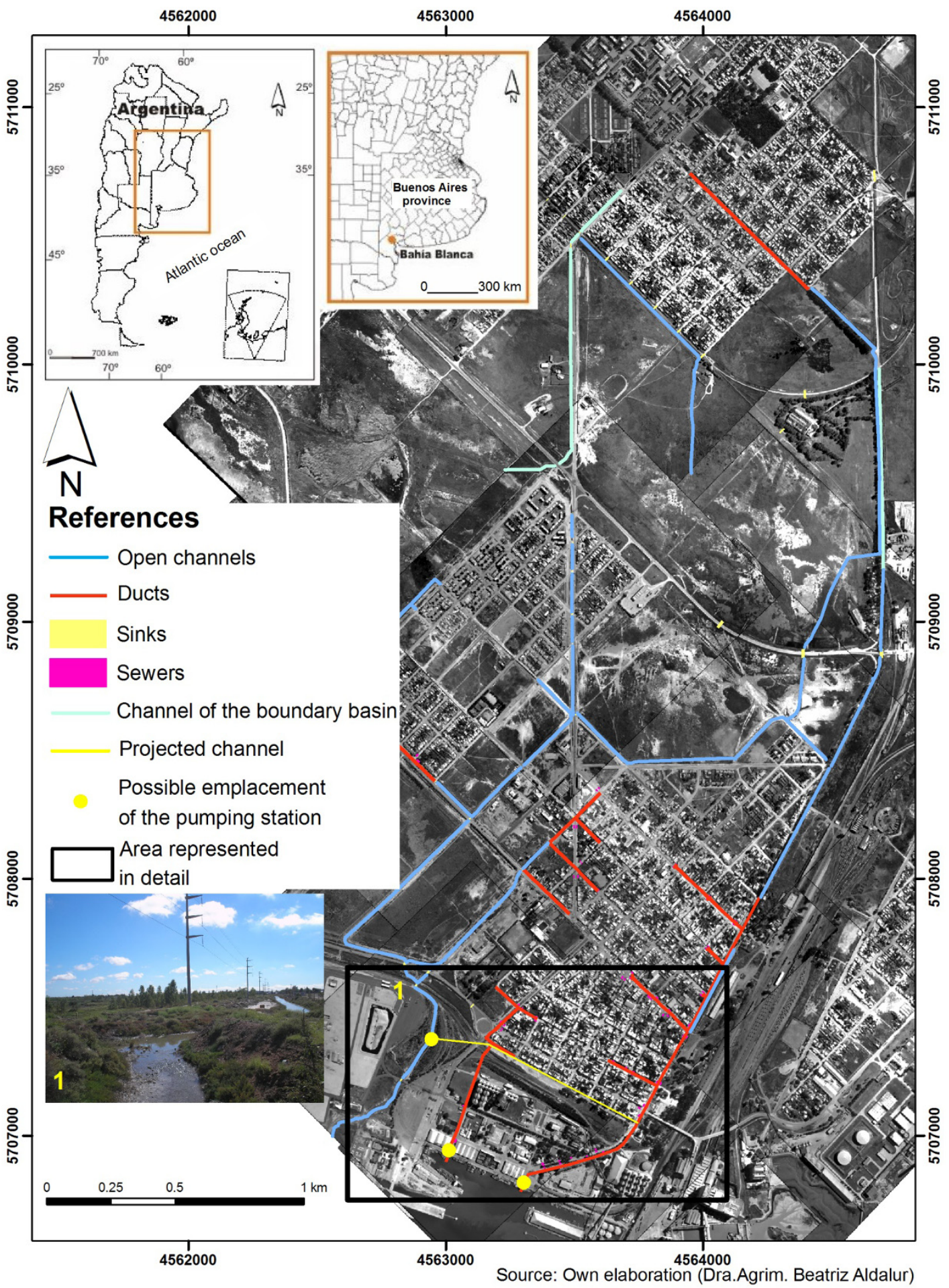

Figure 7. Location of the proposed channel and pumping stations. 


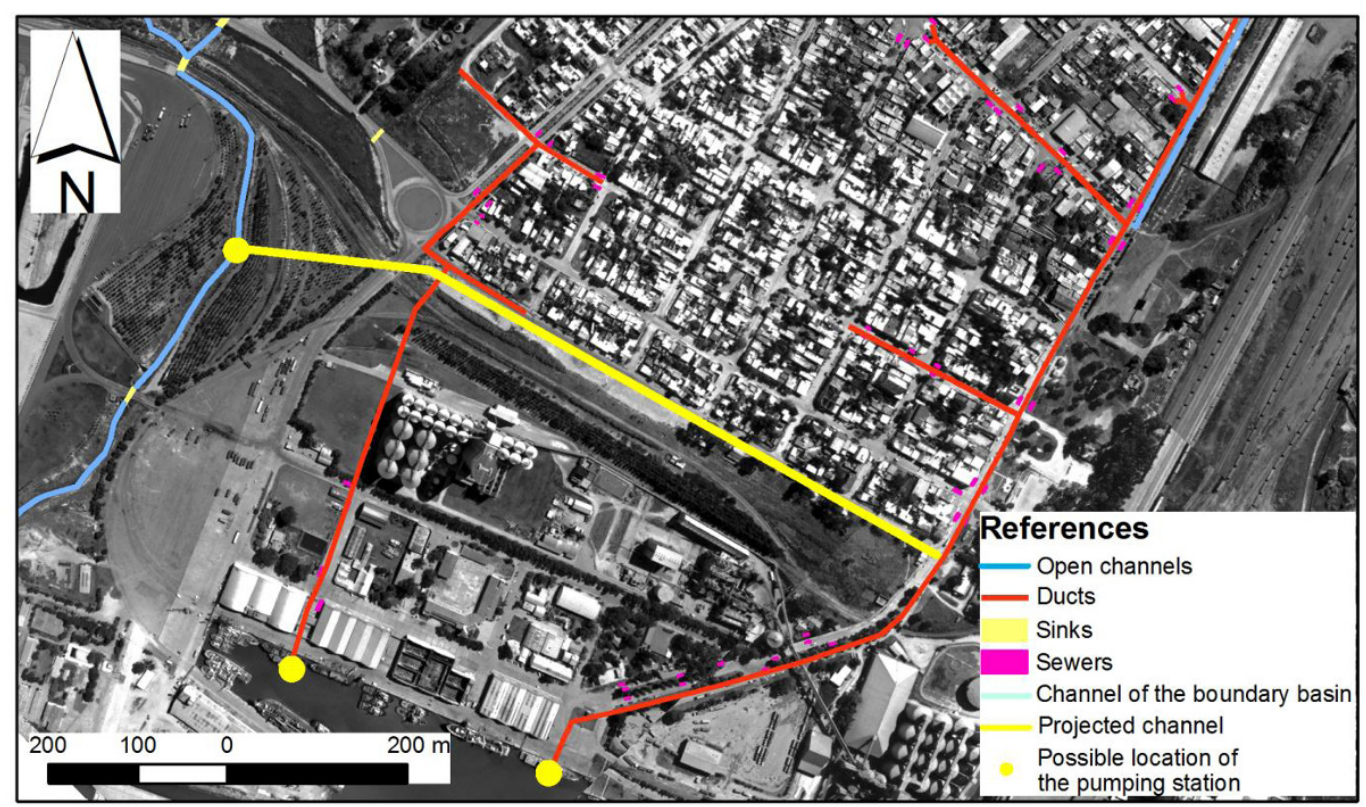

Source: Own elaboration (Dra.Agrim. Beatriz Aldalur)

Figure 8. Enlarged detail of Figure 7.

of open channels made in recent years, the improvement in Profertil channel and the change of rainwater pipes in some roads, it is observed that all these works made to solve the problems in the area have not emerged from a global study of the area.

\section{References}

[1] Gentile E., González S., Social vulnerability to floods in Buenos Aires City (Argentina). The cases of La Boca neighborhood and the basin of Maldonado stream, Open Meeting of the Human Dimensions of Global Environmental Change Research Community, Rio de Janeiro, Brasil, 2001

[2] Campo de Ferreras A., Capelli de Steffens A., Diez P., El clima del suroeste bonaerense, Departamento de Geografía y Turismo, Universidad Nacional del Sur, Bahía Blanca, Argentina, 2004

[3] Benedetti G., Las Contribuciones Geográficas de Alcides D'Orbigny al conocimiento de la flora y fauna del área de Bahía Blanca, $49^{\circ}$ Congreso Internacional del Americanistas (ICA), Quito, Ecuador, 1997. Available at: www.antropologia.com.ar/congresos/
contenido/49CAI/Benedetti.htm

[4] Verettoni H., Aramayo E., Comunidades vegetales de la región de Bahía Blanca, Harris Ed., Bahía Blanca, 1976

[5] Chuvieco E., Bosque J., Pons J., Conesa, C., et al., ¿Son las Tecnologías de la Información Geográfica (TIG) parte del núcleo de la Geografía?, Boletín de la Asociación de Geógrafos Españoles, AGE, España, 2005, 40, 35-55

[6] Ehrensperger A., Wymann von Dach S., Kakridi Enz F., Tecnologías de Información Geográfica para el manejo de los recursos naturales, Focus, Schlaefli \& Maurer AG, Suiza, 2007, 3. Available at: http: //www.inforesources.ch/pdf/focus07_3_s.pdf

[7] Gentili J., Gil V., Aplicación de Tecnologías de Información Geográficas (TIG) al análisis hidrogeomorfológico. Caso de estudio: cuencas hidrográficas del Sistema de Ventania. Buenos Aires. Argentina, $12^{\circ}$ Encuentro de geógrafos de América Latina "Caminando en una América Latina en transformación", Montevideo, Uruguay, 2009

[8] Hidalgo D., Alvarez C., Salazar B., Lazcano A., et al., Las Tecnologías de Información Geográfica y su aplicación al análisis urbano. El caso del 
estudio de los espacios residenciales cerrados en las áreas metropolitanas de Santiago y Valparaíso, Scripta Nova, Revista electrónica de Geografía y Ciencias Sociales, Universidad de Barcelona, 2004, VIII, 170 (31). Available at: http://www.ub.es/geocrit/ sn/sn-170-31.htm

[9] Buzai G., Baxendale C., Análisis Socioespacial con Sistemas de Información Geográfica, $1^{\text {st }}$ ed., Lugar Editorial, Buenos Aires, Argentina, 2006

[10] Aldalur N. B., Inundaciones y anegamientos en Ingeniero White. Aplicación de Tecnologías de la Información Geográfica para la planificación y gestión de la hidrología urbana, Tesis Doctoral, Universidad Nacional del Sur, Bahía Blanca, Argentina, 2011

[11] Del Cogliano D., Napal E., Di Croche N., Aldalur N. B., et al., Control de cartas topográficas con GPS, ISPRS, Bahía Blanca, 1998, XXXII, 6W4, 142-147

[12] Perdomo R., Del Cogliano D., Di Croche N., Napal E., et al., Red Geodésica con técnicas GPS, V Jornadas Geológicas y Geofísicas Bonaerenses, Mar del Plata, Argentina, 1998, II, 191-195

[13] Murga N., Diseño y construcción de desagües pluviales urbanos y suburbanos. Curso de postgrado, Departamento de Ingeniería, Universidad Nacional del Sur, Bahía Blanca, Argentina, 2003

[14] Senciales González J., Redes fluviales. Metodología de análisis, Universidad de Málaga, 1999

[15] Provincial Department of Sanitation and Water Works - MOSP, Normas para la presentación de proyectos de desagüe aprobadas por disposición no. 1170, Provincia de Buenos Aires, 1995
[16] Pérez Morales G., Rodríguez Castro J., Apuntes de Hidrología Superficial, Universidad Michoacana de San Nicolás de Hidalgo, México, 2009

[17] Castillo Sánchez V., Estabilización de cauces torrenciales, Determinación de caudales máximos en pequeñas cuencas, Curso de Formación continua, Escuela Universitaria de Ingeniería Técnica Forestal, Universidad Politécnica de Madrid, 1989. In: Senciales González J., Redes fluviales. Metodología de análisis, Universidad de Málaga, España, 1999

[18] Chow V., Maidment D., Mays L., Hidrología aplicada, Editorial McGraw-Hill, Santa Fe de Bogotá, Colombia, 1999

[19] Villón Béjar M., HidroEsta, software para cálculos hidrológicos. Tecnología en Marcha, 2008, vol. 18, no. 2 Especial, Costa Rica, 67-75

[20] Kirpich P., Time of concentration of small agricultural watershed, Civil Engineering, USA, 1940, vol. 10, no. 6, 362-363

[21] Sequeira M., Determinación de la relación entre la intensidad, la duración y la frecuencia de las precipitaciones en Bahía Blanca, Actas de las IV Jornadas Interdisciplinarias del Sudoeste Bonaerense, Universidad Nacional del Sur, Bahía Blanca, Argentina, 2006, 69-78

[22] Villón Béjar M., HCanales para Windows. Manual del usuario, Editorial Tecnológica de Costa Rica, 1994

[23] Chow V., Hidráulica de canales abiertos, Editorial McGraw-Hill, Santa Fe de Bogotá, Colombia, 1998 